\title{
AN INVESTIGATION OF PHYSICAL ACTIVITY LEVELS OF ACADEMICIANS IN SPORT SCIENCES - THE EXAMPLE OF MARMARA UNIVERSITY AND ISTANBUL GELIŞIM UNIVERSITY, TURKEY
}

\author{
Ömer Eryiğitit ${ }^{1 \mathrm{i}}$ \\ Serap Mungan $\mathrm{Ay}^{2}$ \\ ${ }^{1}$ Graduate Student, \\ Marmara University, \\ Institute of Health Sciences, \\ Turkey \\ ${ }^{2}$ Assistant Professor, \\ Marmara University, \\ Faculty of Sport Sciences, \\ Turkey
}

\begin{abstract}
:
The aim of this study is to examine the physical activity levels of academicians working at the sports science faculties of state and foundation universities. The sample group of the study consists of academicians working at Marmara University and Istanbul Gelişim University. As a data collection tool in research, in addition to the personal information form "International Physical Activity questionnaire", developed by the World Health Organization and adapted to Turkish by Öztürk (2005) was used. In the evaluation of the data, besides descriptive statistics, Chi-Square test was used. As a result of the analysis, a difference was found between the physical activity levels of the academicians working at Marmara University according to their gender, age and monthly income level. No statistically significant difference was found between the gender, age, marital status, weekly lesson hours, university service years, monthly income and body mass indexes and physical activity levels of the academicians working at Istanbul Gelişim University. As a result, it has been determined that the participation levels of the academicians working in the sports science faculties of state and foundation universities differ in terms of some socio-demographic characteristics.
\end{abstract}

Keywords: academician, physical activity, sports sciences

i Correspondence: email omer.yigitt@hotmail.com, smunganay@marmara.edu.tr 


\section{Introduction}

Physical activity is described as the bodily actions that occur as a result of the contraction of the muscles in the skeletal system, enabling effort to be exerted above the basic level (Kırbaş, 2020). In another definition, energy is wasted as a result of stimulation of the muscles with a force above the resting level (Kalaycı M. C. et al., 2016). In other words, all activities that provide energy consumption can be called physical activity. The goal of physical activity, increasing endurance, strength and flexibility, eliminating the lack of muscle and joint actions, decreasing body fat and reaching the ideal weight (Tayar et al., 2011). Although physical activity is used by many individuals in the same sense as exercise and sports, these are different concepts from each other. The following comment was made for physical activity. The energy consumed by the movements of the individual through his muscles, that is, the energy consumed by an individual in a day (A $\breve{g} ı$ rbaş Ö. et al.).

World Health Organization (WHO), on the other hand, includes physical activity; It is defined as physical movements that consume energy, including activities performed while working, doing housework, traveling or entertainment. One fourth of the adults aged 18 and over in the world do not have enough physical activity, when we look at the distribution by gender; one in five people in males and more than one in four in females have been reported as inactive. Despite physical activity that plays an important role in preventing non-communicable diseases; physical inactivity is an important risk factor for non-communicable diseases such as cardiovascular diseases, cancer and diabetes. Today's technological developments cause people to stay still more and more every day and spend a large part of their time sitting or lying still. In recent years, especially with the developments in computer games, there is a period in which children, young people and adults are more inactive. In the report of the World Health Organization in 2002, it was stated that sedentary life causes 1.9 million deaths per year. This published research is sufficient evidence to reveal the great role of physical activity in an individual's life. It is highly important for people to spend their time outside of their business life by filling them with physical activities, not technological devices. It is necessary to attach importance to the continuity of these activities in order to have a healthier and more energetic life. As a result of some studies, it has been stated that physical activities at medium and high levels protect from some types of cancer and reduce the risk of death (Canbolat, 2018). In addition, continuous physical activities allow people to eliminate nutritional problems, get away from bad habits, increase their energy, and be more successful in communication with other people (Akyol et al., 2008). In order to maintain a quality, happy and healthy life, it is necessary to stay away from stress, to resist diseases by increasing body resistance, to pay attention to our nutrition, sleep, rest and to pay attention to regular physical activities. Many studies have given this result (Zorba, 2008).

Physical activity areas: business activities, school activities, home activities, transportation activities and finally leisure activities can be examined in five areas. Business activities: weight-bearing, walking, manual work, work done by sitting, work 
done with machinery (heavy vehicle or work machine), work done by walking or climbing stairs are some examples to be given in this field. School activities: sitting, walking, running, playing, climbing stairs, movements within the scope of physical education lessons and sports activities are some examples that can be given in this field. Home activities: small works at home, work done while resting at home, house cleaning (washing or washing dishes, ironing), reading books, watching television, child or elderly care, personal care and gardening are some examples that can be given in this field. Transportation activities: walking for transportation purposes, cycling, climbing and descending stairs, standing in a vehicle for transportation purposes, skating, skating, going with a vehicle, riding a motorcycle are also examples to be given in this field. Leisure activities: swimming, playing football, handball, table tennis, fencing, hockey, tennis, horseback riding, cycling or walking for exercise can be given as examples in this field.

The 21st century we are in is called the information age. Scientific and technological developments that have accelerated in the 21st century have added many innovations to our lives and continue to do so. In order to maintain the continuity of the society, equipped people were needed who could produce, share and compete with knowledge. Therefore, universities that activate the social dynamics, evaluate and shape the information obtained and enrich the information by interpreting it according to the age, and the academics they host are of great importance. In this context, the aim of the study is to examine the physical activity levels of sports science academics working at state and foundation universities.

\section{Method}

\subsection{Research Model}

This research, which aims to examine the physical activity levels of academic staff working in the field of sports sciences of state and foundation universities, is a research based on quantitative data. Screening models are research approaches that aim to describe a situation that still exists in the past or present. The individual or object discussed in the research is tried to be defined in its own conditions and as it is (Karasar, 2020).

\subsection{Research Group}

The study sample at Marmara University in Turkey and Istanbul Gelişim University, Faculty of Sports Sciences Situated within the guard is composed of 104 academics.

\subsection{Data Collection Tools}

\subsubsection{Personal Information Form}

In the first part, "Personal Information Form" prepared by the researcher was used. Individuals participating in the research in the Personal Information Form; age, gender, 
marital status, title, average monthly income, area of expertise, years of service, work intensity information were determined.

\subsubsection{International Physical Activity Questionnaire}

Researchers from various countries developed the "International Physical Activity Questionnaire" with the support of the World Health Organization (WHO) and Centers for Disease Control and Prevention (CDC). In the study, the long form of the "International Physical Activity Questionnaire", which was adapted to Turkish by Öztürk (2005), was used. The questionnaire consists of 27 questions and 5 sub-dimensions. The sub dimensions are: (1) Physical Activities Related to Work, (2) Physical Activities Related to Transportation, (3) Physical Activities Related to Housework, (4) Physical Activities Related to Free Time and (5) Time Spent Sitting.

\subsubsection{Data Evaluation}

During the evaluation of the data, the data obtained from the surveys were analyzed in the SPSS program. After analyzing the frequency and percentage distributions of the data, the Kolmogorov-Smirnov test was applied to determine whether they showed normal distribution, and the Chi-square test was used to examine the relationship between categorical variables because the data showed normal distribution.

\section{Results}

Table 1: Distribution of Participants Personal Information

\begin{tabular}{|c|c|c|c|}
\hline Variables & & $\mathbf{F}$ & $\%$ \\
\hline \multirow[t]{3}{*}{ Gender } & Male & 52 & 54,8 \\
\hline & Female & 43 & 45,2 \\
\hline & Total & 95 & 100,0 \\
\hline \multirow[t]{5}{*}{ Age } & $21-30$ & 11 & 11,6 \\
\hline & $31-40$ & 28 & 29,5 \\
\hline & $41-50$ & 25 & 26,3 \\
\hline & 51 years and older & 31 & 32,6 \\
\hline & Total & 95 & 100,0 \\
\hline \multirow{5}{*}{$\begin{array}{l}\text { Marital } \\
\text { Status }\end{array}$} & Married & 65 & 68,4 \\
\hline & Single & 23 & 24,2 \\
\hline & Divorced & 5 & 5,3 \\
\hline & Widowed & 2 & 2,1 \\
\hline & Total & 95 & 100,0 \\
\hline \multirow{6}{*}{$\begin{array}{l}\text { Weekly } \\
\text { Lesson } \\
\text { Hours }\end{array}$} & $0-6$ hours & 18 & 18,93 \\
\hline & 7-14 hours & 21 & 22,09 \\
\hline & 15-18 hours & 20 & 21,04 \\
\hline & 19-22 hours & 17 & 17,88 \\
\hline & 23 and more & 19 & 19,99 \\
\hline & Total & 95 & 100,0 \\
\hline \multirow{2}{*}{$\begin{array}{l}\text { Service } \\
\text { Year }\end{array}$} & $1-3$ years & 22 & 23,2 \\
\hline & 4-6 years & 15 & 15,8 \\
\hline
\end{tabular}


AN INVESTIGATION OF PHYSICAL ACTIVITY LEVELS OF ACADEMICIANS IN SPORT SCIENCES THE EXAMPLE OF MARMARA UNIVERSITY AND İSTANBUL GELIŞIM UNIVERSITY, TURKEY

\begin{tabular}{|l|l|c|c|}
\hline \hline \multirow{4}{*}{$\begin{array}{l}\text { Monthly } \\
\text { Revenue }\end{array}$} & Tyears and more & 58 & 61,0 \\
\cline { 2 - 4 } & Total & $\mathbf{9 5}$ & $\mathbf{1 0 0 , 0}$ \\
\cline { 2 - 4 } & $\leq 6000 \mathrm{TL}$ & 24 & 25,3 \\
\cline { 2 - 4 } & $6001-8000$ & 22 & 23,2 \\
\cline { 2 - 4 } & $8001-10000$ & 21 & 22,1 \\
\cline { 2 - 4 } & $10001-12000$ & 11 & 11,5 \\
\cline { 2 - 4 } & $\geq 12001 \mathrm{TL}$ & 17 & 17,9 \\
\cline { 2 - 4 } & Total & $\mathbf{9 5}$ & $\mathbf{1 0 0 , 0}$ \\
\hline \multirow{5}{*}{ BMI } & Weak & 0 & 0,0 \\
\cline { 2 - 4 } & Normal weight & 42 & 44,2 \\
\cline { 2 - 4 } & Overweight & 76 & 48,4 \\
\cline { 2 - 4 } & Obese & $\mathbf{9 5}$ & $\mathbf{1 0 0 , 0}$ \\
\cline { 2 - 4 } & Total & & \\
\hline
\end{tabular}

Table 1 includes the distribution of the personal information of the participants of the research. As a result of the analysis, $54.8 \%$ of the participants in the study were found to be "Male", while $32.6 \%$ were "51 years old and over".

Table 2: Socio-demographic characteristics of MU participants and physical activity levels according to MET

\begin{tabular}{|c|c|c|c|c|c|c|c|c|}
\hline \multicolumn{9}{|c|}{ IPAQ BY MET SCORE (MU) } \\
\hline \multirow{2}{*}{\multicolumn{2}{|c|}{ Variables }} & \multirow{2}{*}{\multicolumn{2}{|c|}{$\begin{array}{c}\text { Low } \\
\text { Physical } \\
\text { Activity } \\
(n=2)\end{array}$}} & \multirow{2}{*}{\multicolumn{2}{|c|}{$\begin{array}{c}\text { Middle } \\
\text { Physical } \\
\text { Activity } \\
(\mathbf{n}=17) \\
\%\end{array}$}} & \multirow{2}{*}{\multicolumn{2}{|c|}{$\begin{array}{c}\text { High } \\
\text { Physical } \\
\text { Activity } \\
(\mathrm{n}=45)\end{array}$}} & Statistics \\
\hline & & & & & & & & $\%$ \\
\hline Gender & $\begin{array}{l}\text { Female } \\
\text { Male }\end{array}$ & $\begin{array}{l}2 \\
0\end{array}$ & $\begin{array}{l}8,0 \\
0,0\end{array}$ & $\begin{array}{c}11 \\
6 \\
\end{array}$ & $\begin{array}{l}44,0 \\
15,4\end{array}$ & $\begin{array}{l}12 \\
33\end{array}$ & $\begin{array}{l}48,0 \\
84,6\end{array}$ & $\begin{array}{c}\chi_{2}=10,721 \\
p=0,005\end{array}$ \\
\hline Age & $\begin{array}{l}21-30 \text { years } \\
31-40 \text { years } \\
41-50 \text { years } \\
51 \text { and older }\end{array}$ & $\begin{array}{l}0 \\
0 \\
2 \\
0\end{array}$ & $\begin{array}{l}0,0 \\
0,0 \\
8,7 \\
0,0 \\
\end{array}$ & $\begin{array}{l}2 \\
2 \\
6 \\
5 \\
\end{array}$ & $\begin{array}{c}100,0 \\
14,3 \\
26,1 \\
23,8 \\
\end{array}$ & $\begin{array}{c}0 \\
12 \\
15 \\
16 \\
\end{array}$ & $\begin{array}{c}0,0 \\
85,7 \\
65,2 \\
76,2 \\
\end{array}$ & $\begin{array}{c}\chi 2=10,395 \\
p=0,03\end{array}$ \\
\hline $\begin{array}{l}\text { Marital } \\
\text { Status }\end{array}$ & $\begin{array}{l}\text { Married } \\
\text { Single } \\
\text { Divorced } \\
\text { Widowed }\end{array}$ & $\begin{array}{l}2 \\
0 \\
0 \\
0\end{array}$ & $\begin{array}{l}4,0 \\
0,0 \\
0,0 \\
0,0\end{array}$ & $\begin{array}{c}13 \\
3 \\
1 \\
0 \\
\end{array}$ & $\begin{array}{c}26,0 \\
42,9 \\
20,0 \\
0,0\end{array}$ & $\begin{array}{c}35 \\
4 \\
4 \\
2 \\
\end{array}$ & $\begin{array}{c}70,0 \\
57,1 \\
80,0 \\
100,0 \\
\end{array}$ & $\begin{array}{c}\chi^{2}=2,368 \\
p=0,883\end{array}$ \\
\hline $\begin{array}{l}\text { Weekly } \\
\text { Lesson } \\
\text { Hours }\end{array}$ & $\begin{array}{l}0-6 \text { hours } \\
7-14 \text { hours } \\
15-18 \text { hours } \\
19-22 \text { hours } \\
23 \text { and more }\end{array}$ & $\begin{array}{l}1 \\
1 \\
0 \\
0 \\
0\end{array}$ & $\begin{array}{l}6,3 \\
7,1 \\
0,0 \\
0,0 \\
0,0 \\
\end{array}$ & $\begin{array}{l}3 \\
7 \\
2 \\
3 \\
2\end{array}$ & $\begin{array}{l}18,8 \\
50,0 \\
20,0 \\
42,9 \\
11,8 \\
\end{array}$ & $\begin{array}{c}12 \\
6 \\
8 \\
4 \\
15\end{array}$ & $\begin{array}{l}75,0 \\
42,9 \\
80,0 \\
57,1 \\
88,2 \\
\end{array}$ & $\begin{array}{c}\chi^{2}=10,446 \\
p=0,235\end{array}$ \\
\hline $\begin{array}{l}\text { Service } \\
\text { Year }\end{array}$ & $\begin{array}{l}1-3 \text { years } \\
4-6 \text { years } \\
7 \text { and more }\end{array}$ & $\begin{array}{l}0 \\
0 \\
2\end{array}$ & $\begin{array}{l}0,0 \\
0,0 \\
3,6 \\
\end{array}$ & $\begin{array}{c}0 \\
3 \\
14 \\
\end{array}$ & $\begin{array}{c}0,0 \\
42,9 \\
25,5 \\
\end{array}$ & $\begin{array}{c}2 \\
4 \\
39 \\
\end{array}$ & $\begin{array}{c}100,0 \\
57,1 \\
70,9 \\
\end{array}$ & $\begin{array}{c}\chi^{2}=2,010 \\
p=0,734\end{array}$ \\
\hline $\begin{array}{l}\text { Monthly } \\
\text { Revenues }\end{array}$ & $\begin{array}{l}\leq 6000 \mathrm{TL} \\
6001-8000 \\
8001-10000 \\
10001-12000\end{array}$ & $\begin{array}{l}0 \\
0 \\
0 \\
1\end{array}$ & $\begin{array}{c}0,0 \\
0,0 \\
0,0 \\
11,1\end{array}$ & $\begin{array}{l}0 \\
3 \\
6 \\
4\end{array}$ & $\begin{array}{c}0,0 \\
21,4 \\
46,2 \\
44,4\end{array}$ & $\begin{array}{c}11 \\
11 \\
7 \\
4\end{array}$ & $\begin{array}{c}100,0 \\
78,6 \\
53,8 \\
44,4\end{array}$ & $\begin{array}{c}\chi^{2}=6,796 \\
p=0,042\end{array}$ \\
\hline
\end{tabular}


AN INVESTIGATION OF PHYSICAL ACTIVITY LEVELS OF ACADEMICIANS IN SPORT SCIENCES -

THE EXAMPLE OF MARMARA UNIVERSITY AND İSTANBUL GELISSIM UNIVERSITY, TURKEY

\begin{tabular}{|l|l|c|c|c|c|c|c|c|}
\hline \hline BMI & $\geq 12001$ TL & 1 & 6,7 & 4 & 26,7 & 10 & 66,7 & \\
& Weak & 0 & 0,0 & 0 & 0,0 & 0 & 0,0 & \\
& Normal weight & 2 & 9,1 & 7 & 31,8 & 13 & 59,1 & $\mathbf{\chi 2}=\mathbf{6 , 6 5 5}$ \\
& Overweight & 0 & 0,0 & 8 & 23,5 & 26 & 76,5 & $\mathbf{p}=\mathbf{0 , 3 2 5}$ \\
& Obese & 0 & 0,0 & 2 & 28,6 & 5 & 71,4 & \\
\hline$\chi 2=$ Chi-square test \\
$\mathrm{p}=$ Sig. "significance"
\end{tabular}

In Table 2, socio-demographic characteristics of "MU" Participants and their physical activity levels are given to MET Levels. According to the analysis results it was observed that the participants' total MET scores according to IPAQ were minimum 297, maximum $10314 \mathrm{MET}$ min / week. The overall average of the participants was determined as 4278.40 MET min / week. While this average was $4267.05 \mathrm{MET}$ min / week for MU, it was found as 4301.82 MET min / week for IGU. Considering the average values of physical activity on the basis of gender, the average value for MU women is 3123.52; "MU" is 5000.08 meters / $\mathrm{min} /$ week for men.

While $70.3 \%(\mathrm{n}=45)$ of the total number of "MU" participants had high physical activity level, $26.6 \%(n=17)$ had moderate and $3.1 \%(n=2)$ has been found to have low physical activity. According to gender, $48 \%(\mathrm{n}=12)$ of women had high, $44 \%(\mathrm{n}=11)$ moderate, and $8 \%(n=2)$ had low level of physical activity of the participants, while $84.6 \%$ of men $(\mathrm{n}=33)$ high, $15.4 \%(\mathrm{n}=6)$ showed a distribution at moderate physical activity level. No male participants with low PA levels were found in "MU" participants.

An important difference was found between the physical activity levels of Marmara University participants by gender. It was determined that; the physical activity level of male participants was higher and a statistically important difference was found $(\chi 2=10.721 ; p=0.005)$. An important difference was found between the age distribution of the participants and their physical activity levels. As the age interval progressed, the physical activity level of those who do physical activity was found to be higher and a statistically important difference was found $(\chi 2=10.395 ; \mathrm{p}=0.03)$. An important difference was found between monthly income and physical activity level. As the monthly income decreased, the level of physical activity increased, and a statistically important difference was found $(\chi 2=6.796 ; p=0.042)$. There was no statistically important difference between marital status, weekly course hours, university years of service, body mass indexes and physical activity levels ( $p>0.05$ ).

In Table 3, the socio-demographic characteristics of IGU Participants and their physical activity levels are given to MET Levels. According to the analysis results: the average physical activity value of the academicians participating in the study was found to be 4301.82 meters / min / week for IGU. Considering the average values of physical activity on the basis of genders, the average value for IGU is 4450.50 for women, while it is 4095.96 meters / $\mathrm{min}$ / week for men. 
Table 3: Socio-demographic characteristics of IGU participants and physical activity levels according to MET

\begin{tabular}{|c|c|c|c|c|c|c|c|c|}
\hline \multicolumn{9}{|c|}{ IPAQ BY MET SCORE (IGU) } \\
\hline \multicolumn{2}{|l|}{ Variables } & \multicolumn{2}{|c|}{$\begin{array}{c}\text { Low } \\
\text { Physical } \\
\text { Activity } \\
(\mathbf{n}=2)\end{array}$} & \multicolumn{2}{|c|}{$\begin{array}{c}\text { Middle } \\
\text { Physical } \\
\text { Activity } \\
(\mathrm{n}=17)\end{array}$} & \multicolumn{2}{|c|}{$\begin{array}{c}\text { High } \\
\text { Physical } \\
\text { Activity } \\
(\mathrm{n}=45)\end{array}$} & \multirow[t]{2}{*}{ Statistics } \\
\hline & & $\mathbf{n}$ & $\%$ & $\mathbf{n}$ & $\%$ & $\mathbf{n}$ & $\%$ & \\
\hline Gender & $\begin{array}{l}\text { Female } \\
\text { Male }\end{array}$ & $\begin{array}{l}0 \\
0\end{array}$ & $\begin{array}{l}0,0 \\
0,0\end{array}$ & $\begin{array}{l}6 \\
6\end{array}$ & $\begin{array}{l}33,3 \\
46,2\end{array}$ & $\begin{array}{l}12 \\
33\end{array}$ & $\begin{array}{l}66,7 \\
53,8\end{array}$ & $\begin{array}{c}\chi^{2}=0,523 \\
p=0,470\end{array}$ \\
\hline Age & $\begin{array}{l}21-30 \text { years } \\
31-40 \text { years } \\
41-50 \text { years } \\
51 \text { and older }\end{array}$ & $\begin{array}{l}0 \\
0 \\
0 \\
0\end{array}$ & $\begin{array}{l}0,0 \\
0,0 \\
0,0 \\
0,0\end{array}$ & $\begin{array}{l}3 \\
3 \\
0 \\
6\end{array}$ & $\begin{array}{c}37,5 \\
23,1 \\
0,0 \\
66,7 \\
\end{array}$ & $\begin{array}{c}5 \\
10 \\
1 \\
3 \\
\end{array}$ & $\begin{array}{c}62,5 \\
76,9 \\
100,0 \\
33,3 \\
\end{array}$ & $\begin{array}{l}\chi 2=4,940 \\
p=0,176\end{array}$ \\
\hline $\begin{array}{l}\text { Marital } \\
\text { Status }\end{array}$ & $\begin{array}{l}\text { Married } \\
\text { Single } \\
\text { Divorced } \\
\text { Widowed } \\
\end{array}$ & $\begin{array}{l}0 \\
0 \\
0 \\
0\end{array}$ & $\begin{array}{l}0,0 \\
0,0 \\
0,0 \\
0,0\end{array}$ & $\begin{array}{l}8 \\
4 \\
0 \\
0\end{array}$ & $\begin{array}{c}53,3 \\
25,0 \\
0,0 \\
0,0\end{array}$ & $\begin{array}{c}7 \\
12 \\
0 \\
0\end{array}$ & $\begin{array}{c}46,7 \\
75,0 \\
0,0 \\
0,0\end{array}$ & $\begin{array}{l}\chi 2=2,620 \\
p=0,106\end{array}$ \\
\hline $\begin{array}{l}\text { Weekly } \\
\text { Lesson } \\
\text { Hours }\end{array}$ & $\begin{array}{l}0-6 \text { hours } \\
7-14 \text { hours } \\
15-18 \text { hours } \\
19-22 \text { hours } \\
23 \text { and more } \\
\end{array}$ & $\begin{array}{l}0 \\
0 \\
0 \\
0 \\
0\end{array}$ & $\begin{array}{l}0,0 \\
0,0 \\
0,0 \\
0,0 \\
0,0 \\
\end{array}$ & $\begin{array}{l}1 \\
3 \\
5 \\
3 \\
0\end{array}$ & $\begin{array}{c}50,0 \\
42,9 \\
50,0 \\
30,0 \\
0,0 \\
\end{array}$ & $\begin{array}{l}1 \\
4 \\
5 \\
7 \\
2 \\
\end{array}$ & $\begin{array}{c}50,0 \\
57,1 \\
50,0 \\
70,0 \\
100,0 \\
\end{array}$ & $\begin{array}{c}\chi 2=2,278 \\
p=0,685\end{array}$ \\
\hline $\begin{array}{l}\text { Service } \\
\text { Year }\end{array}$ & $\begin{array}{l}1-3 \text { years } \\
4-6 \text { years } \\
7 \text { and more }\end{array}$ & $\begin{array}{l}0 \\
0 \\
0\end{array}$ & $\begin{array}{l}0,0 \\
0,0 \\
0,0\end{array}$ & $\begin{array}{l}7 \\
4 \\
1 \\
\end{array}$ & $\begin{array}{l}35,0 \\
50,0 \\
33,3 \\
\end{array}$ & $\begin{array}{c}13 \\
4 \\
2 \\
\end{array}$ & $\begin{array}{l}65,0 \\
50,0 \\
66,7 \\
\end{array}$ & $\begin{array}{c}\chi^{2}=0,582 \\
p=0,747\end{array}$ \\
\hline $\begin{array}{l}\text { Monthly } \\
\text { Revenues }\end{array}$ & $\begin{array}{l}\leq 6000 \mathrm{TL} \\
6001-8000 \\
8001-10000 \\
10001-12000 \\
\geq 12001 \mathrm{TL}\end{array}$ & $\begin{array}{l}0 \\
0 \\
0 \\
0 \\
0\end{array}$ & $\begin{array}{l}0,0 \\
0,0 \\
0,0 \\
0,0 \\
0,0\end{array}$ & $\begin{array}{l}5 \\
1 \\
2 \\
1 \\
1\end{array}$ & $\begin{array}{c}45,5 \\
14,3 \\
28,6 \\
100,0 \\
100,0 \\
\end{array}$ & $\begin{array}{l}6 \\
6 \\
5 \\
0 \\
0\end{array}$ & $\begin{array}{c}54,5 \\
85,7 \\
71,4 \\
0,0 \\
0,0 \\
\end{array}$ & $\begin{array}{c}\chi 2=5,503 \\
p=0,239\end{array}$ \\
\hline BMI & $\begin{array}{l}\text { Weak } \\
\text { Normal Weight } \\
\text { Overweight } \\
\text { Obese }\end{array}$ & $\begin{array}{l}0 \\
0 \\
0 \\
0\end{array}$ & $\begin{array}{l}0,0 \\
0,0 \\
0,0 \\
0,0\end{array}$ & $\begin{array}{l}0 \\
6 \\
6 \\
0\end{array}$ & $\begin{array}{c}0,0 \\
33,3 \\
50,0 \\
0,0\end{array}$ & $\begin{array}{c}0 \\
12 \\
6 \\
0\end{array}$ & $\begin{array}{c}0,0 \\
66,7 \\
50,0 \\
0,0\end{array}$ & $\begin{array}{c}\chi^{2}=0,833 \\
p=0,361\end{array}$ \\
\hline
\end{tabular}

While $61.3 \%(n=19)$ of the total number of "IGU" participants had high physical activity, $38.7 \%(n=12)$ had moderate physical activity, it was determined that there were no participants with low physical activity. According to gender, $66.7 \%(n=12)$ of the IGU participants were high in females, $33.3 \%(n=6)$ were medium, while $53.8 \%(n=7)$ of males were high, $46 \%$, 2 of them $(n=6)$ were determined to be at the moderate physical activity level. Participants with low levels of PA were not found among the IGU participants. 
No statistically significant difference was found between IGU participants' gender, age, marital status, weekly course hours, university service year, monthly income and body mass indexes and physical activity levels ( $p>0.05)$.

\section{Discussion and Conclusion}

According to the gender variables of the sports science academics at state and foundation universities, for "MU", looking at the statistics on physical activity levels, it was found that there was a significant difference in terms of the gender variable of the academicians with low physical activity, moderate physical activity and high physical activity. Again, in the same variable for IGU; considering the statistics on physical activity levels, it was found that there was no significant difference in terms of gender variable.

In Salih (2016), in his study for Firat University academic staff, he concluded that the average of male academicians is higher than the average of female academicians and there is a statistically significant difference. Çiğdem (2008) found that the physical activity levels of men are higher than women.

According to the age variable, for "MU", considering the statistics on physical activity levels, a significant difference was found between low, medium and high physical activity levels and the age variable of academicians. Again, in the same variable for IGU; when the statistics about physical activity levels were examined, it was found that there was no significant difference regarding the age variable.

Arabacı and Çankaya (2007) found in their study on physical education teachers that there is a positive difference between age variable and physical activity levels. Canan (2012) found no statistically significant difference between the age groups and the physical activity level of the subjects in his study for the personnel working at Sakarya University.

When we examine the relationship between physical activity levels according to monthly income variables of the participants in the study, for MU; A significant and statistical difference was found between monthly income and physical activity level. No such meaning has been determined for IGU.

Kizar et al. (2016), while a significant statistical difference was found between income level and low-intensity physical activity, no significant difference was found for the variables of intensive physical activity and moderate physical activity. In another study, Aytekeli (2019), as a result of the Kruskal-Wallis H test, which was conducted to test whether the monthly income of the participants was related to the PA levels, it was determined that the monthly income did not affect the PA levels of the participants.

According to the marital status variable, there was no significant and statistical difference between academicians and physical activity level. In Özüdoğru (2013), which is a similar study, when the physical activity levels are considered according to the marital status of academic and administrative staff, no statistically significant difference was observed. 
There was no statistically significant difference between the marital status, weekly course hours, university service years, body mass indexes and physical activity levels of the participants.

The characteristics of the participants included in the study such as gender, age, marital status, work intensity, years of service, monthly income and body mass index were determined and evaluated. The findings were interpreted and the validity and reliability of the results of the study we obtained were increased by comparing the data of previous similar studies with the results of our own study.

According to the results of the study, similar significant differences were not found between the physical activity levels and socio-demographic characteristics of the participating academicians from state and foundation universities. Contrary to the study conducted at Istanbul Gelişim University, a significant difference was found between some of the socio-demographic variables and physical activity levels in Marmara University. These significant statistical differences, while it is obtained in gender, age and monthly income variables, other variables are, no meaningful outcome could be obtained from marital status, weekly course hours, university years of service and body mass indexes. Quality of life scale was not used in our study. Using the quality-of-life scale together with the physical activity questionnaire in future studies is important in terms of determining the size of the relationship between the two scales. Again, for future researches more comprehensive results can be achieved by expanding the sampling group that includes a sample of sports sciences from state and foundation universities. Based on the results, a comprehensive study is recommended to compare state and foundation universities and reveal their differences or similarities.

\section{Conflict of Interest Statement}

The authors declare no conflict of interest.

\section{About the Authors}

Ömer Eryiğit was born in Istanbul in 1993. Between 2013-2017, he graduated from Marmara University, Faculty of Sport Sciences, Department of Sports Management. Between 2017-2020, he completed his master's degree in Marmara University Institute of Health Sciences, Department of Physical Education and Sports, Management Sciences Program.

Dr. Serap Mungan Ay was born in Ankara in 1969. He graduated from Istanbul University, Faculty of Economics, Department of Economics between 1989-1990. Marmara University he completed his master's degree at the Institute of Health Sciences, Physical Education and Sports Department, Sports Management Program in 1995. Marmara University she graduated from the Institute of Health Sciences, Department of Physical Education and Sports, Sports Management Program in 2002. Marmara University Sports Management Department, in 2006, she received the title of assistant professor. She did academic studies in the field of sports management and sports economics. Member of the Association of Sports Sciences. 


\section{References}

Ağırbaş Ö. et al. (2019). Investigation of Physical Activity Levels of High School Students According to their Exercise Addiction. Atatürk University Journal of Physical Education and Sport Sciences. Volume: 21 Issue: 2, June.

Akyol A., Bilgiç P., Ersoy G. (2008). Nutrition and Healthy Lifestyle. Klasman Matbaacilık, Ankara.

Arabacı ve Çankaya (2007). Investigation of Physical Activity Levels of Physical Education Teachers. Uludağ University, Journal of Education Faculty.

Aytekeli S. T. (2019). Determination of Nutrition Habits and Physical Activity Levels of University Students. Master Thesis, İnönü University, Institute of Educational Sciences, Physical Education and Sports Department, Malatya, 2019.

Cana H. (2012). Determination of Physical Activity Levels, Some Physical Characteristics and Physical Fitness Levels of Personnel Working at Sakarya University. Master Thesis, Sakarya University, Institute of Educational Sciences, Physical Education and Sport Department, Sakarya.

Canbolat D. (2018). Investigation of Physical Activity Level and Self-Esteem in Teachers. Master Thesis, Selcuk University, Institute of Health Sciences, Coaching Education Department, Konya.

Kalaycı M. C., Eroğlu H. (2016). Investigation of Sexual Life in Adult Men According to Physical Activity Level. CBU Journal of Physical Education and Sport Sciences.

Karasar N. (2020). Scientific research method: Concepts, principles, techniques. 2. Spelling 35th Edition.

Kırbaş Ş. (2020). Investigation of the Relationship between Physical Activity Level and Quality of Life of Youth and Sports Provincial Directorate Personnel. Gazi Journal of Physical Education and Sport Sciences, pp.213-224.

Kizar O. et al. (2016). Investigation of University Students' Physical Activity Levels. Marmara University Journal of Sport Sciences, June.

Öner S. (2016). Determination of Physical Activity Levels of Academic Staff Working at Firat University. Firat University, Physical Education and Sports Department, Master Thesis.

Öztürk M. (2005). Determining the validity and reliability of the international physical activity questionnaire and physical activity levels of students studying at the university. Master Thesis, Institute of Health Sciences, Hacettepe University, Ankara.

Özüdoğru E. (2013). Investigation of the Relationship Between University Personnel Physical Activity Level and Quality of Life. Master Thesis, Mehmet Akif Ersoy University, Institute of Educational Sciences, Department of Physical Education and Sports, Burdur.

Şanlı E. (2008). Physical Activity Level-Age, Gender and Body Mass Index Relationship in Teachers. Master. Ankara: Gazi University.

Tayar M., Korkmaz H., Özkeleş H. (2011). Nutrition Principles. Bursa, p.253. 
Tekkanat Ç. (2008). Quality of Life and Physical Activity Levels of Students in the Teaching Department. Pamukkale University, Institute of Health Sciences, Department of Psycho-Social Fields in Sport, Master Thesis.

Zorba E. (2008). Quality of Life and Physical Activity. 10th International Sport Sciences Congress, Congress Booklet, pp.82-85, 23-25, Bolu, October. 

be applied to their work. Under the terms of this license, no permission is required from the author(s) or publisher for members of the community to copy, distribute, transmit or adapt the article content, providing a proper, prominent and unambiguous attribution to the authors in a manner that makes clear that the materials are being reused under permission of a Creative Commons License. Views, opinions and conclusions expressed in this research article are views, opinions and conclusions of the author(s). Open Access Publishing Group and European Journal of Physical Education and Sport Science shall not be responsible or answerable for any loss, damage or liability caused in relation to/arising out of conflict of interests, copyright violations and inappropriate or inaccurate use of any kind content related or integrated on the research work. All the published works are meeting the Open Access Publishing requirements and can be freely accessed, shared, modified, distributed and used in educational, commercial and non-commercial purposes under a Creative Commons attribution 4.0 International License (CC BY 4.0). 